DOI: 10.20472/IAC.2018.044.025

BRUNELA KULLOLLI

“Aleksander Moisiu" University of Durres, Albania

\title{
ILRIJAN HYSA
}

I.S.K Law Firm, Albania

\section{THE RIGHT TO A FAIR TRIALIN CRIMINAL LAW. LEGAL TIME LIMITS}

\begin{abstract}
:
The object of this paper is the challenge related with the justice system, and in particular with one of its fundamental principles that is the right to a fair trial especially in criminal law. The right to a fair trial in criminal law is analyzed in all of its elements but a particular focus is reserved to the legal time limits.

The first part gives, Legal time limits in a legal system based on the democratic principles constitute a fundamental right in the procedural as well in the human aspect.

The second part is concentrated, Legal time limits are a constitutional guarantee as the country's highest law, but also legal guarantees stemming from the conventions that the Albanian state has ratified. They include a period of time within which the criminal procedure action is to be carried out and are measured according to clearly defined criteria in the Criminal Procedure Code.

The third part, case law on the violation of the right to a fair trial (legal time limits)

Conclusions The overview provided in this article will focus on law enforcement in practical court cases, in the implementation by the prosecution of the procedures during both detention of arrest, investigation and detention. Practical observation confirms that sending arrestees to a judge within 48 hours from the moment of arrest occurs only as an exception and it is not uncommon for them to appear before the judge 4 or 5 days after the arrest.According to some indicators, longer delays may come as a result of the incorrect practice of starting counting hours not at the moment of arrest.
\end{abstract}

\section{Keywords:}

criminal law, legal guarantees, legal time limits, Fundamental Rights, case law, fair trial.

JEL Classification: K14 